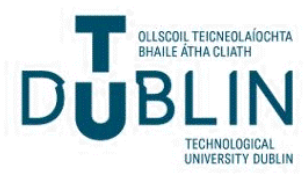

Technological University Dublin

ARROW@TU Dublin

\section{The Effect of Delactosed Whey Permeate on Phytochemical Content of Canned Tomatoes.}

\author{
Lubna Ahmed \\ Technological University Dublin, lubna.ahmed@tudublin.ie \\ Ankit Patras \\ Technological University Dublin \\ Ana Belen Martin-Diana \\ Technological University Dublin, anabelen.martindiana@tudublin.ie
}

See next page for additional authors

Follow this and additional works at: https://arrow.tudublin.ie/schfsehart

Part of the Food Chemistry Commons

\section{Recommended Citation}

Ahmed, L., Patras, A., Martin-Diana, A., Rico, D. and Barry-Ryan, C. The Effect of Delactosed Whey Permeate on Phytochemical Content of Canned Tomatoes.. Food chemistry, 2012 Oct 15;134(4):2249-56. doi: 10.1016/j.foodchem.2012.04.104

This Article is brought to you for free and open access by the School of Food Science and Environmental Health at ARROW@TU Dublin. It has been accepted for inclusion in Articles by an authorized administrator of ARROW@TU Dublin. For more information, please contact arrow.admin@tudublin.ie, aisling.coyne@tudublin.ie, gerard.connolly@tudublin.ie.

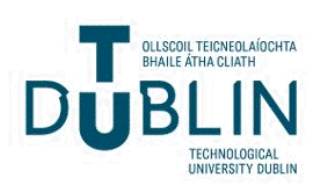




\section{Authors}

Lubna Ahmed, Ankit Patras, Ana Belen Martin-Diana, Daniel Rico, and Catherine Barry-Ryan

This article is available at ARROW@TU Dublin: https://arrow.tudublin.ie/schfsehart/109 

PHYTOCHEMICAL CONTENT OF CANNED TOMATOES

Lubna Ahmed ${ }^{\mathrm{a} *}$, Ankit Patras ${ }^{\mathrm{b}}$, Ana B. Martin-Diana ${ }^{\mathrm{c}}$, Daniel Rico ${ }^{\mathrm{c}}$ and Catherine

Corresponding Author: Lubna Ahmed, School of Food Science and Environmental

23 Health, Dublin Institute of Technology (DIT), Cathal Brugha Street, Dublin 1, Ireland.

24 Phone: 35314024442, Fax: +35314024495, e-mail: lahmed@ dit.ie 


\section{ABSTRACT:}

26 The effect of delactosed whey permeate (DWP) treatment on antioxidant and phyto-chemical

27 components of canned Irish plum tomatoes were investigated. Tomatoes were sterilized for 5

$28 \min \left(\mathrm{F}_{0}\right)$ at $120{ }^{\circ} \mathrm{C}$ and stored for 6 months. The DWP treatment retained significantly

$29(\mathrm{p}<0.05)$ higher levels of ascorbic acid and lycopene of tomatoes. The antioxidant activity of

30 DWP treated tomatoes was higher $(7 \%)$ than the control at the end of storage. The firmness

31 in DWP-treated fruits was around $40 \%$ higher than that in control. All the parameters

32 decreased significantly $(\mathrm{p}<0.05)$ during storage except lycopene and total phenols. Lycopene

33 content showed no significant change and total phenols increased during storage. The

34 changes in ascorbic acid, antioxidant activity and texture were fitted well to Weibull kinetic

35 models with high coefficients of determination $\left(\mathrm{R}^{2}\right)$ and low RMSEC (root mean sum of

36 squared error). The results clearly indicate that DWP enhanced the retention of antioxidant

37 compounds in tomatoes during storage.

38 Key words: Delactosed whey permeate; canned tomato; processing; antioxidants; Weibull. 


\section{Introduction}

41 Food canning has been one classical way to provide a continuous supply of food independently of the seasonal availability of raw materials. Acidification and thermal treatment are two widely used methods in preservation of canned fruits and vegetables.

44 Canning processes extend the shelf life of the products and make it safe for human consumption by destroying the pathogenic microorganisms. The sterilization of the canned food is usually carried out by steam heating to a temperature sufficient to kill the microorganisms. However, thermal processing of food is often considered to cause losses of micronutrients (Seybold, Fröhlich, Bitsch, Otto \& Böhm, 2004). Optimum thermal sterilization of food always requires a compromise between the beneficial and destructive influences of heat on the food. On the positive side, heat destroys microbial pathogens, spoilage organisms and endogenous and introduced enzymes that would otherwise render the food inedible or unsafe. At the same time, concentrations of heat-labile vitamins, particularly thiamine, vitamin $\mathrm{C}$ and folate are reduced. In many foods, organoleptic quality is reduced by

54 the heat of the sterilization process. The texture of canned vegetables is often softer than desired (Durance, 1997). Both physical and chemical changes occur during processing and, to

56 a lesser extent, during storage, and it is these that determine the product quality in terms of its sensory properties and nutrient content. These physicochemical changes are influenced by the time and temperature of the process, the composition and properties of the food, the canning medium, and the conditions of storage (Patras, Brunton, Pieve, Butler \& Downey, 2009).

60 Tomato (Lycopersicon esculentum Mill.) is a versatile vegetable that is consumed fresh as 61 well as in the form of processed products with more than $65 \%$ of the world tomato production being processed. It is considered as an important source of dietary antioxidants as

63 it is rich in vitamins, carotenoids and phenolic compounds (Toor \& Savage, 2005). Results

64 from epidemiological studies have shown that high consumption of tomato fruit is 
consistently correlated with a reduced risk of chronic diseases such as cardiovascular disease and certain types of cancer (Sgherri, Kadlecova, Pardossi, Navari-Izzo \& Izzo, 2008). The increase in the consumers' awareness of the health benefits of tomatoes is leading to an increase of tomato consumption. Retention of the quality and shelf-life of fresh tomato and processed tomato products is now the interest of the industry and consumers.

Whey permeate is a by-product of the production of whey protein concentrate from cheese whey. The main components of whey permeate are water, lactose, peptides and minerals. Whey and whey permeate have been proposed to be used as a natural antioxidant in foods (Contreras, Hernández-Ledesma, Amigo, Martín-Álvarez \& Recio, 2011). Enzymehydrolysed whey protein is widely used as a bioactive and nutritional ingredient in health and food products (Marshall, 2004). Previous studies have shown that whey protein hydrolysates contain a broad range of antioxidant activity in an iron-catalysed liposome oxidation system (Peña-Ramos \& Xiong, 2003) or a copper-catalysed liposome emulsion (Colbert \& Decker, 1991), depending on the proteases used. Whey hydrolysates applied to cooked meat pork patties could suppress lipid oxidation (Peña-Ramos \& Xiong, 2003). Acidic whey permeate was successfully used for decontamination of fresh-cut lettuce and carrots during storage (Martin-Diana, Rico, Frias, Mulcahy, Henehan \& Barry-Ryan, 2006). Delactosed whey permeate could enhance the antioxidant activity of the fresh-cut tomato while retaining the antioxidant components of tomatoes during storage (Ahmed, Martin-Diana, Rico \& BarryRyan, 2011a, b, c, d).

Kinetic models are often used for an objective, fast and economic assessment of food safety and food quality. Kinetic modelling may also be employed to predict the influence of processing on critical quality parameters. Weibull distribution function has an interesting potential for describing microbial, enzymatic and chemical degradation kinetics (Cunha et al., 1998). Traditionally, the degradation of nutrients in foods during their thermal processing and 
90 storage has been described in terms of zero, first or higher order kinetics (Taoukis et al.,

91 1997). However, Weibull model is extremely flexible owning to the inclusion of a shape

92 constant in addition to the rate constant.

93 Therefore the objective of this study was to investigate the efficacy of delactosed whey

94 permeate treatment on retention of the phytochemical contents of canned tomatoes during 95 storage and to model the changes in antioxidant activity, phenols, ascorbic acid, lycopene, 96 texture and colour parameters.

\section{$97 \quad 2 . \quad$ Materials and Methods}

\subsection{Sampling}

Irish vine ripened plum tomatoes (Lycopersicon esculentum L. Mill.) cv. Moneymaker were

100 purchased from a local grower. According to the grower, the tomato plants were grown 101 commercially in a greenhouse with a $14 \mathrm{~h}$ light period from February until November. The aerial environment of the greenhouse, crop irrigation and nutrition were precisely controlled. The temperature of the greenhouse was $16-21^{\circ} \mathrm{C}$ which is optimum for lycopene synthesis in tomato fruits. The tomatoes were then brought to the food processing laboratory and stored at $4{ }^{\circ} \mathrm{C}$ before processing. The experiments were carried out between June to November

1062010.

\subsection{Preparation of treatment solution}

108 Liquid delactosed whey permeate (DWP) was supplied by Glanbia Ingredients Ltd.,

109 Kilkenny, Ireland. DWP was obtained after removal of lactose crystals from cheese whey

110 permeate. In this experiment DWP was used at $3 \%(\mathrm{v} / \mathrm{v})$ concentration as optimised in a

111 previous research (Ahmed, Martin-Diana, Rico \& Barry-Ryan, 2011b). The solution was

112 prepared using distilled water stored at room temperature. The main components of DWP 113 were given in Table 1. 
114 2.3. Preparation of Tomato samples for processing

115 Whole tomatoes were rinsed in tap water prior to washing in order to avoid soil

116 contamination. In order to facilitate packing and eliminate dissolved gases within the tissues,

117 the tomatoes were water-blanched for $1 \mathrm{~min}$ at $100{ }^{\circ} \mathrm{C}$ in a steam-jacketed kettle and then

118 quickly cooled in ice cold water to peel the skin. Approximately $200 \mathrm{~g}$ tomatoes were added

119 to each can $(75 \times 110 \mathrm{~mm}$, WEI/WEISS03, Germany). The tomatoes were topped with 100

$120 \mathrm{ml}$ solution ( $3 \% \mathrm{DWP}+0.5 \% \mathrm{NaCl}+0.25 \%$ citric acid) with $6-10 \%$ headspace at room

121 temperature. The control treatment was $0.5 \% \mathrm{NaCl}+0.25 \%$ citric acid.

122

\subsection{Canning Experiment}

123 The prepared cans were loaded into a pilot scale retort (Barriquand Steriflow, Roanne,

124 France). Sample core temperature profiles and $\mathrm{F}_{0}$ values were recorded during the process, 125 using an Ellab E-Val TM TM9608 data module (Ellab [UK] Ltd., Norfolk, England) 126 connected to a laptop. A standard Ellab SSA-12080-G700-TS temperature probe was inserted 127 through an Ellab GKM-13009-C020 packing gland $(20 \mathrm{~mm})$ into a tomato placed in a can to 128 record the cook cycle. Temperature was monitored every $10 \mathrm{~s}$. The samples were heated to 129 achieve a process equivalent to $121{ }^{\circ} \mathrm{C}$ for $5 \mathrm{~min}$ at the end of the cook-cool cycle and 130 samples were stored for 6 months at room temperature. Prior to any canning experiment, all 131 Ellab unit probes were calibrated against a JOFRA (ATC-155B) calibration unit at 132 temperatures of $121{ }^{\circ} \mathrm{C}$ and the result associated with the calibration did not exceed $\pm 0.1^{\circ} \mathrm{C}$.

\section{2.4. Biomarkers Analysis of Canned Tomatoes}

134 Ascorbic acid, lycopene, total phenols, antioxidant activity (as measured by DPPH and 135 FRAP), texture and colour parameters of canned tomatoes were monitored over 6 months 136 stored at room temperature.

137 2.4.1. Ascorbic acid 
138 Ascorbic acid in tomatoes was analysed by HPLC with a slight modification of the method 139 described by Lee and Castle (2001). A tomato sample (1.25 g freeze-dried powder) was 140 weighed and $25 \mathrm{ml}$ of $6 \%$ metaphosphoric acid (pH 3.0) was added to it. The sample was 141 then homogenized for $1 \mathrm{~min}$ at 24,000 rpm using an Ultra-Turrax T-25 Tissue homogenizer 142 (USA). Then the sample was shaken with a Gyratory Shaker G-2 (USA) for 2 hrs at 150 rpm 143 and centrifuged for $15 \mathrm{~min}$ at 3,000 $\times \mathrm{g}$ at $4{ }^{\circ} \mathrm{C}$ (Sanio MSE Mistral 3000ii, UK). Following 144 centrifugation, $10 \mathrm{ml}$ of the supernatant was filtered through PTFE syringe filters (pore size $1450.45 \mu \mathrm{m}$, Phenomenex, UK) and stored at $-20{ }^{\circ} \mathrm{C}$ in foil covered plastic test tubes for further 146 analysis by HPLC. The analysis of ascorbic acid content was performed with Waters 600

147 Satellite HPLC, with a reversed phase analytical $5 \mu \mathrm{m}$ particle diameter, polymeric $\mathrm{C}_{18}$ 148 column $(150 \times 4.6 \mathrm{~mm}, 5 \mu \mathrm{m})$ (Waters, Dublin, Ireland) with a UV-tuneable absorbance 149 detector (Waters 486) at $230 \mathrm{~nm}$. Ten $\mu \mathrm{l}$ of the tomato sample was injected. An isocratic 150 mobile phase of $25 \mathrm{mM}$ monobasic potassium phosphate ( $\mathrm{pH} 3.0)$ with a flow rate of $1.0 \mathrm{ml} /$ min was used. Five concentrations of ascorbic acid standard in $6 \%$ metaphosphoric acid in the range $10-50 \mu \mathrm{g} / \mathrm{ml}$ were injected and peak area and height were determined.

\subsubsection{Lycopene}

154 A tomato sample (1.25 g freeze-dried powder) was weighed and transferred into a $100 \mathrm{ml}$ 155 beaker (wrapped with aluminium foil). A 50-ml volume of hexane-acetone-ethanol solution $156(2: 1: 1 \mathrm{v} / \mathrm{v} / \mathrm{v})$ containing $2.5 \%$ BHT was added to solubilise the lycopene (Shi \& Le Maguer, 157 2000). Following this the samples were homogenized with an Ultra-Turrax T-25 tissue 158 homogenizer for $1 \mathrm{~min}$ at 20,500 rpm. The samples were then shaken with a Gyrotory Shaker 159 G-2 (USA) for $2 \mathrm{hrs}$ at $150 \mathrm{rpm}$ followed by $10 \mathrm{ml}$ of distilled water was added and stirred

160 for additional $10 \mathrm{~min}$. The polar and non-polar layers were separated, and the upper hexane 161 layer was collected and filtered through a $0.45 \mu \mathrm{m}$ PVDF membrane filter. It was transferred 162 to a new $15 \mathrm{ml}$ aluminium wrapped test tubes and kept at $-80{ }^{\circ} \mathrm{C}$ till analysis. The analysis of 
163 lycopene was performed with Waters 600 Satellite HPLC, with a reversed phase analytical 5

$164 \mu \mathrm{m}$ particle diameter, polymeric $\mathrm{C}_{18}$ column $(150 \times 4.6 \mathrm{~mm}, 5 \mu \mathrm{m})$ (Waters, Ireland) with a

165 UV tuneable absorbance detector (Waters 486) at $475 \mathrm{~nm}$. An isocratic mobile phase of 166 methyl t-butyl ether/methanol/ethyl acetate (40:50:10, v/v) with a flow rate of $1 \mathrm{ml} / \mathrm{min}$ was

167 used. The column temperature and mobile phase was maintained at $25^{\circ} \mathrm{C}$. Analyses were

168 performed under dim light to prevent sample degradation by photo-oxidation. Three 169 concentrations of lycopene standard in the range $0.01-0.03 \mathrm{mg} / \mathrm{ml}$ were injected and peak 170 area and peak height were determined.

\section{$171 \quad$ 2.4.3. Total phenols}

172 For extraction, $25 \mathrm{ml}$ of methanol was added to $1.25 \mathrm{~g}$ freeze-dried powder and homogenized 173 in a $50 \mathrm{ml}$ tube with an Ultra-Turrax T-25 tissue homogenizer for $1 \mathrm{~min}$ at 24,000 rpm. The 174 samples were then thoroughly mixed with a vortex mixer (V400 Multituve Vortexer, Alpha laboratories) for $2 \mathrm{hrs}$ at $150 \mathrm{rpm}$. Then they were centrifuged for $15 \mathrm{~min}$ at 3,000 $\times \mathrm{g}$ using a Sanyo MSE Mistral 3000i, UK. Following centrifugation, $10 \mathrm{ml}$ samples of the supernatant were filtered through PTFE syringe filters (pore size $0.45 \mu \mathrm{m}$, Phenomenex, UK). The extracts were then stored at $-20{ }^{\circ} \mathrm{C}$ in foil covered plastic test tubes for further analysis. Total phenol content of tomatoes was determined using the Folin-Ciocalteu method (Singleton,

180 Orthofer \& Lamuela-Raventos, 1999). In a $1.5 \mathrm{ml}$ Eppendorf tube, $100 \mu \mathrm{l}$ of appropriately 181 diluted methanolic extract, $100 \mu \mathrm{l}$ of $\mathrm{MeOH}$ and $100 \mu \mathrm{l}$ of FC reagent were added and 182 vortexed. After exactly $1 \mathrm{~min}, 700 \mu \mathrm{l}$ of sodium carbonate (20\%) was added, and the mixture was vortexed and allowed to stand at room temperature in the dark for $20 \mathrm{~min}$. Then the tubes were centrifuged at $12,720 \times \mathrm{g}$ for $3 \mathrm{~min}$. The absorbance of the supernatant was read at 735 $\mathrm{nm}$ in $1 \mathrm{ml}$ plastic cuvettes. Each sample of the three batches was measured in triplicate.

186 Results were expressed as mg/L gallic acid equivalents (GAE). 


\subsubsection{2, 2-Diphenyl-l-picrylhydrazyl radical scavenging capacity assay (DPPH)}

189 DPPH scavenging activity assay was performed as per the method described by Sanchez-

190 Moreno (2002) with a slight modification. The extraction was done as per the phenol content

191 of tomato (section 2.4.3). For DPPH assay, In a 1.5-ml Eppendorf tube $500 \mu \mathrm{l}$ of appropriately diluted methanolic extract and $500 \mu \mathrm{l}$ DPPH Reagent were added and vortexed. After that they were kept for 30 min in dark. The absorbance of the supernatant was read at

$194515 \mathrm{~nm}$ in $1 \mathrm{ml}$ plastic cuvettes. Each sample of the three batches was measured in triplicate.

\subsubsection{Ferric ion reducing antioxidant power assay (FRAP)}

196 The FRAP assay was carried out as described by Stratil, Klejdus and Kuban (2006) with a 197 slight modification. The extraction was done as per the phenol content of tomato (section 2.4.3). The FRAP reagent was prepared by mixing $38 \mathrm{mM}$ sodium acetate (anhydrous) in distilled water $(\mathrm{pH} 3.6), 20 \mathrm{mM} \mathrm{FeCl} 3 \cdot 6 \mathrm{H}_{2} \mathrm{O}$ in distilled water and $10 \mathrm{mM}$ 2,4,6-tri(2pyridyl)-s-triazine (TPTZ) in $40 \mathrm{mM} \mathrm{HCl}$ in proportions of 10:1:1. This reagent was freshly prepared before each experiment. In a $1.5 \mathrm{ml}$ Eppendorf tube $100 \mu \mathrm{l}$ of appropriately diluted methanolic extract and $900 \mu \mathrm{l}$ FRAP Reagent were added and vortexed. After that they were kept for $40 \mathrm{~min}$ in the heating blocks at $37{ }^{\circ} \mathrm{C}$, covered with aluminium foil. The absorbance of the supernatant was read at $593 \mathrm{~nm}$ in $1 \mathrm{ml}$ plastic cuvettes. Each sample of the three batches was measured in triplicate.

\subsubsection{Firmness}

207 Firmness was measured using an Instron texture analyser (Instron 4302 Universal Testing 208 Machine, Canton MA, USA), with a $3.5 \mathrm{~mm}$ diameter flat faced cylindrical probe. The 209 maximum force $(\mathrm{N})$ necessary to cause a deformation of $3 \mathrm{~mm}$ with a speed of $0.2 \mathrm{~mm} / \mathrm{s}$ was 
210 recorded. The puncture test was performed on the equatorial zone of each fruit. Data were

211 analyzed with the Instron series IX software for Windows.

212 2.4.6. Colour

213 Colour was quantified using a Colour Quest XE colorimeter (HunterLab, Northants, UK).

214 Tomatoes were placed directly on the colorimeter sensor (3.5 $\mathrm{cm}$ of diameter) and measured

215 (Ahmed et al., 2011b). 20 - 30 measurements were taken per treatment and day. The L*

216 parameter (lightness index scale) range from 0 (black) to 100 (white). The $a^{*}$ parameter

217 measures the degree of red $\left(+a^{*}\right)$ or green $\left(-a^{*}\right)$ colour and the $b^{*}$ parameter measures the

218 degree of yellow $\left(+b^{*}\right)$ or blue $\left(-b^{*}\right)$ colour. The CIE L* $a^{*} b^{*}$ parameters were converted to

219 Hue $\left(\arctan b^{*} / a^{*}\right)$ and Chroma $\left(a^{* 2}+b^{* 2}\right)^{1 / 2}$.

$220 \quad$ 2.4.7. Sensory analysis

221 Sensory analysis was performed for canned tomato samples over 6 months of storage time by

222 a panel with an age range of $25-40$ years. Colour, texture, aroma and general acceptability of samples were scored on a scale of 1 to 9 , where a score of one indicated a product of very poor quality, etc (Ferreira, Pinho, Amaral \& Martins, 2008). The evaluation was carried out in the sensory evaluation laboratory. Products were coded using random numbers to avoid bias. Products were placed in plastic cups with lid, on a white surface and judges were isolated from each-other in a booth in an odour-free environment. The sensory analysis was monitored with Compusense Five software (Release 4.4, Ontario, Canada).

\subsubsection{Statistical Analysis}

230 Data were analysed by multivariate analysis of variance (MANOVA) using Statgraphics

231 software (version: Centurium XV; Statistical Graphics Co., Rockville, USA) for different 232 treatments. Analysis of variance one-way (ANOVA) was used to analyse each treatment over 233 storage. In the case of significant differences the LSD range test $(\mathrm{p}<0.05)$ was used. Data are 
234 presented as means \pm standard deviation of 3 replicates of three batches. Relative changes in 235 AA, DPPH, FRAP and texture were described using Weibull model (Equation 1). The

236 Weibull model represents the distribution of the breaking strength of materials and later to 237 describe the behavior of systems or events that have some degree of variability. It is flexible 238 owing to the inclusion of a shape constant in addition to the rate constant and has been 239 employed to describe microbial, enzymatic and chemical degradation kinetics (Manso, 240 Oliveira, Oliveira \& Frías, 2001; Cunha, Oliveira \& Oliveira, 1998).

$241 C_{t}=C_{0} \times e^{-(K t)^{\beta}}$ Equation 1

242 where $\mathrm{Ct}$ is $\mathrm{AA}, \mathrm{DPPH}, \mathrm{FRAP}$ and texture values at time $\mathrm{t}, \mathrm{C}_{0}$ is the initial AA, DPPH, 243 FRAP and texture values, $\mathrm{K}$ is the rate constant $\left(\right.$ month $^{-1}$ ) and $\beta$ (dimensionless) is the shape 244 constant. Modelling and analysis of variance was performed using SAS Statistical software 245 (SAS Version 9.1, SAS Institute, Cary, NC). The goodness of fit was assessed by regression 246 coefficient of determination along with an analysis of residuals. The fitting ability of the 247 tested models was also evaluated by calculating the root mean squared error (RMSE) 248 (Equation 2) (Neter, Wasserman \& Whitmore, 1992).

$$
\text { RMSE }=\sqrt{\sum_{i=1}^{n_{t}} \frac{\left(y_{\text {exp } i}-y_{\text {pre }}\right)^{2}}{n_{t}-n_{p}}} \quad \text { Equation } 2
$$

250 where $\mathrm{y}_{\text {expi }}$ are experimental observations, $\mathrm{y}_{\text {pre }}$ are model predictions, $\mathrm{n}_{\mathrm{t}}$ are number of data 251 points and $n_{p}$ are number of estimated model parameters.

\section{$252 \quad 3 . \quad$ Results and Discussion}

\subsubsection{Ascorbic Acid}

254 The initial content of ascorbic acid in canned tomatoes was found to be $135-145 \mathrm{mg} / 100 \mathrm{~g}$ 255 DW, which is in the range of those reported elsewhere (Patras et al., 2009). Ascorbic acid is 
strongly affected by the various processing techniques. However, significantly $(\mathrm{p}<0.05)$ higher levels of ascorbic acid was found in DWP treated samples compared to control samples $(\mathrm{NaCl}+\mathrm{Citric}$ acid) throughout the storage (Table 2). DWP could have prevented the thermal degradation of ascorbic acid during canning by inhibiting oxidation as well as

260 forming protective layer on the tissue surface. This was accounted for the higher ascorbic 261 acid values of the DWP treated samples before the storage, ie., immediately after canning than control. This was maintained throughout the storage although storage had deteriorating effect on all samples. There was a significant $(\mathrm{p}<0.05)$ decrease in ascorbic acid content in canned tomato over storage. In control samples the decrease was higher $(\sim 30 \%)$ than DWP treated samples $(\sim 22 \%)$ after 6 months of storage. Tomato is a significant dietary source of ascorbic acid and its retention is important for tomato products. The decreasing trend of ascorbic acid was in accordance with the findings of other authors (Lavelli \& Giovanelli, 2003; Ordonez-Santos, Vázquez-Odériz, Arbones-Maciñeira \& Romero-Rodríguez, 2009). The possible reason for the reduction of total ascorbic acid could be autoxidation or oxidation by pro-oxidants generated from other compounds during storage. Oxidation of ascorbic acid to dehydroascorbic acid is followed by hydrolysis of the latter to 2,3-diketogulonic acid, which then undergoes polymerization to other nutritionally inactive products (Dewanto, 273 Adom \& Liu, 2002).

\subsubsection{Lycopene}

Lycopene content of canned tomato was analyzed during 6 months of storage after treatments with DWP. The initial average amount of lycopene in the samples was $117 \mathrm{mg} / 100 \mathrm{~g}$ DW. The DWP treatment showed significant effect $(p>0.05)$ on the lycopene concentration of the samples (Table 2). DWP treatment might have prevented the high temperature induced oxidation of lycopene during canning. Therefore, the samples treated with DWP showed higher lycopene content than the control. In contrast, lycopene content of the samples did not 
281 show significant $(\mathrm{p}<0.05)$ increase or decrease during storage. Tamburini, Sandei, Aldini \& 282 Leoni (1999) and Ordonez-Santos et al. (2009) similarly found no significant change in 283 lycopene of tomato puree during 1-year storage and 6-month storage, respectively. It is well 284 know that lycopene in tomato is relatively resistant to thermal degradation, whereas other 285 antioxidants (ascorbic acid, amino acids and $\beta$-carotene degrade more rapidly during 286 processing and storage (Abushita, Daood \& Biacs, 2000). Dewanto et al. (2002) reported thermal processing increased the extractable lycopene content in processed products when compared to fresh tomatoes. This is probably because lycopene is mostly attached to the skin and insoluble fibre portion of tomatoes (Toor \& Savage, 2005).

\subsubsection{Total phenols}

291 The initial concentration of total phenols in samples was approx 290-305 mg GAE/100 g DW

292 (dry weight) (Table 2). Phenolic contents reported here were within the range of those reported elsewhere (Lavelli \& Giovanelli, 2003; Patras et al., 2009). In the present study total phenol content of the DWP treated tomatoes was significantly $(\mathrm{p}<0.05)$ higher than the control samples throughout storage. DWP was reactive to FCR and therefore had total phenol value although DWP did not contain any phenolic compound. This could be the reason for

297 the higher total phenolic content in the DWP treated samples than other samples. Total phenol content of tomatoes increased in all samples over 6 months of storage. Lavelli and Giovanelli (2003) suggested that the increased total phenol concentrations of canned tomato 300 products may be due to hydrolysis processes. Lavelli, Hippeli, Peri \& Elstner (1999) 301 explained that there could be two reasons for this phenomenon: (1) the release of free

302 hydroxyl groups through hydrolysis of flavonoid glycosides, and (2) the release of phenols by 303 cell walls. The degradation of the cell-wall polysaccharide structures favour the phenol 304 release from skins, notably those phenols that are linked to the cellwall (Pinelo, Arnous \& Meyer, 2006). 


\subsubsection{Antioxidant activity test}

307 3.1.4.1. 2, 2-Diphenyl-1-picrylhydrazyl radical scavenging activity assay (DPPH)

308 The global antioxidant activity as measured by DPPH radical scavenging activity differed 309 significantly $(\mathrm{p}<0.05)$ between treatments (Table 2$)$. The DWP treated tomato samples 310 showed significantly $(\mathrm{p}<0.05)$ higher DPPH reduction than the control samples. The higher

311 antioxidant activity of DWP treated samples could be associated with the intrinsic antioxidant

312 activity of DWP (Ahmed et al., 2011a). DWP might have also helped to retain the antioxidant

313 activity of tomatoes. These results could be related to the total phenolic content of the

314 samples since the samples containing higher phenolic content exhibited stronger DPPH

315 reduction and vice versa. Overall, the antioxidant activity of canned tomatoes deceased with

316 storage time irrespective of the treatments. The average reduction of antioxidant activity of

317 the canned tomatoes was $18 \%$ during 6 months of storage.

318 3.1.4.2. Ferric ion reducing antioxidant power assay (FRAP)

319 Ferric ion reducing antioxidant power (FRAP) is one of the most commonly used antioxidant

320 activity assay (Stratil, Klejdus \& Kuban, 2006). DWP treated samples retained significantly 321 ( $\mathrm{p}<0.05)$ better antioxidant activity as measured by FRAP than control samples (Table 2).

322 FRAP value of canned tomatoes decreased during storage in all three samples. This result 323 was in agreement with the finding of Lavelli and Giovanelli (2003). In control $(\mathrm{NaCl}+$ citric 324 acid) samples the decrease was higher $(\sim 18 \%)$ than DWP treated samples $(\sim 11 \%)$ after 6 325 months of storage. The FRAP values of the tomato sample followed the same trend as DPPH 326 values in the current study. The reduction of antioxidant activity of samples during storage 327 could be attributed to the degradation of ascorbic acid which is one of the main antioxidants 328 in tomato.

\subsubsection{Firmness}


330 Firmness is the most relevant property in quality characterization of the tomatoes processed

331 in the canning industry, in particular, of canned whole tomatoes. It is related to ripeness rate

332 and the tomato susceptibility to damage during harvesting and processing (Arazuri, Jare'n,

333 Arana \& Pe'rez de Ciriza, 2007). DWP treatment markedly inhibited fruit softening and

334 maintained significantly $(\mathrm{p}<0.05)$ greater firmness throughout the storage compared to the

335 control (Table 3). The firmness in DWP-treated fruits was around $40 \%$ higher than that in

336 control fruits at the end of 6 months of storage. The presence of calcium $(\mathrm{Ca})$ in DWP might

337 have contributed to maintenance of this firmness of canned tomatoes during storage (Ahmed

338 et al., 2011b). This effect of Ca can be explained by the formation of cross links between the

339 carboxyl groups of polyuronide chains found in the middle lamella of the cell wall. Ca also

340 increases cell turgor pressure and stabilizes the cell membrane (Shafiee, Taghavi \& Babala,

341 2010; Martin-Diana, Rico, Frias, Barat, Henehan \& Barry-Ryan, 2007). The texture of

342 canned tomatoes decreased gradually during storage.

\section{3.1.6. Colour}

344 Colour is a very important quality factor in fruit and vegetable products, since it influences

345 consumer acceptability. The colour parameters of canned tomatoes for different treatments

346 and storage time are shown in Table 3. There were significant $(\mathrm{p}<0.05)$ differences in $\mathrm{L}^{*}, \mathrm{a}^{*}$

347 and $b^{*}$ values between DWP treated and control samples. DWP treated tomatoes retained

348 brighter colour than the control. The $\mathrm{L}^{*}, \mathrm{a}^{*}$ and $\mathrm{b}^{*}$ values of the tomato samples decrease

349 regardless of the treatment during storage. This was in agreement with the findings of other

350 authors (Liu, Cao, Wang \& Liao, 2010; Lana, Tijskens \& Van Kooten, 2006). The decrease

351 in $\mathrm{L}^{*}$ reflected the darkening of surface colour and characterized the presence of non-

352 enzymatic browning reaction during storage. The decrease in $a^{*}$ and $b^{*}$ indicated less red and

353 less yellow in canned tomato products. Hue was fairly stable but chroma decreased during

354 storage and the decrease was more prominent in control fruits. 


\subsubsection{Sensory analysis}

356 Significant differences $(\mathrm{p}<0.05)$ were observed between DWP treated and control $(\mathrm{NaCl}+$

357 citric acid) canned tomato samples for colour, aroma, texture and general acceptability scores

358 (Figure 1). DWP treated samples scored significantly higher $(\mathrm{p}<0.05)$ than the control 359 samples. The panellists scored the aroma and colour of tomatoes treated with DWP was

360 higher than the control samples. This was in agreement with the other physico-chemical markers of canned tomato studied. Ahmed et al. (2011d) reported that DWP treated fresh-cut tomato samples had higher acceptability than the non-treated samples. All the attributes evaluated decreased significantly $(\mathrm{p}<0.05)$ during storage for all treatments which is associated with a loss of quality. The use of whey permeate for food preservation has also been examined by Nykänen et al. (1998). These authors analyzed the effect of nisin-whey permeate washing solutions on total counts and sensory characteristics in rainbow trout. They found that nisin-whey treatment caused no negative effect on sensory attributes.

4. Weibull model to describe changes in texture and antioxidant composition of tomatoes during storage

The retention of texture, ascorbic acid, DPPH and FRAP values were plotted as a function of various treatments [control $(\mathrm{NaCl}+$ citric acid $), \mathrm{DWP}$ and $\mathrm{DWP}+\mathrm{NaCl}+$ citric acid] and storage (Figures $2 \mathrm{~A}, \mathrm{~B}$ and $3 \mathrm{~A}, \mathrm{~B}$ ). Table 4 shows the results of fitting phytochemical composition of canned tomatoes to the Weibull model distribution. The Weibull model (Eq. 1) yielded good fits to ascorbic acid, DPPH, FRAP and texture experimental data. Weibull model (Eq. 1) was adequate for describing the changes in phytochemical content of canned tomatoes (Table 3). Therefore, Weibull distribution may be suitable for predicting the changes in texture, ascorbic acid, DPPH and FRAP during storage.

Odriozola-Serrano, Soliva-Fortuny and Martín-Belloso (2009) reported that the adequacy of 
strawberries was consistently good in the range of studied temperatures $\left(5-20{ }^{\circ} \mathrm{C}\right)$. Weibull distribution seemed to be suitable because of the high determination coefficients $\left(\mathrm{R}^{2}\right.$ adj $=$ $0.97-0.99)$. The values of kinetic constants $(\mathrm{k})$ and shape constants $(\beta)$ of the Weibull model were obtained by fitting Eq. (1) to the experimental data. The $\mathrm{k}$ and $\beta$ values for texture, ascorbic acid, DPPH and FRAP obtained through Weibull model were directly affected by storage and addition of $\mathrm{NaCl}+$ citric acid, DWP and DWP $+\mathrm{NaCl}+$ citric acid. For texture, values of $\mathrm{k}\left(0.025-0.060 \mathrm{month}^{-1}\right)$ and values for $\beta(0.50-0.98)$ are directly dependent on $\mathrm{NaCl}+$ citric acid, DWP and DWP $+\mathrm{NaCl}+$ citric acid treatments (Figure 2A). DWP exhibited better texture values than other counterparts as evidenced by kinetic parameters (Table 4).

390

The ascorbic acid degradation rate constants were $0.029,0.041 \& 0.047$ for $\mathrm{NaCl}+$ citric acid, DWP and DWP $+\mathrm{NaCl}+$ citric acid treated tomatoes samples respectively (Figure $2 \mathrm{~B}$ ). Similarly $\beta$ increased from 0.84 to 1.16 . The $\beta$ parameter was related to ascorbic acid degradation, the lower the $\beta$ value, the faster the ascorbic acid degradation (Table 4). DPPH and FRAP degradation constants ranged $0.031-0.045$ and $0.021-0.045$ respectively for all the three treatments (Figure $3 \mathrm{~A}, \mathrm{~B}$ ). Whereas $\beta$ values ranged between from $0.93-1.43$ and 1.06- 1.27 for DPPH and FRAP respectively. The $\mathrm{k}$ value increased for DWP $+\mathrm{NaCl}+$ citric acid treated tomatoes samples during storage. The shape factor value for DPPH (Figure 3A) $(\beta<1)$ indicates first order upward concavity for $(\mathrm{NaCl}+$ citric acid $)$ and DWP treatments. Upward concavity $(\beta<1)$ as observed in this study indicates a decreased stability of antioxidant components during storage, whereas downward concavity $(\beta>1)$ would indicate lower degradation rates. The low RMSE values (Table 4) showed that both models gave a good fit for the experimental data analysed.

403 It is quite evident that that Weibull kinetic rate constants for texture, ascorbic acid, DPPH and 404 FRAP were significantly influenced by treatments employed. It should be noted that data for 
total phenols and lycopene did not converge and the models were not significant (data not

406 shown).

\section{5. Conclusion}

408 The application of DWP significantly retained the phytochemical content and maintained 409 firmness of canned tomato throughout the storage, thereby extending the shelf-life of the 410 product. The texture, ascorbic acid, lycopene and total phenol content and the antioxidant 411 activities measured by DPPH and FRAP were significantly $(\mathrm{p}<0.05)$ higher in DWP treated 412 tomato samples than the control samples during storage. Since thermal processing has an 413 adverse effect on retention of most phytochemicals, addition of natural thermo-stable 414 antioxidants like DWP is warranted in food industries. The antioxidant composition of 415 tomatoes was adequately described through a Weibull distribution. Our findings showed that 416 the model based on Weibull distribution function is likely to be a useful tool for describing 417 changes in the antioxidant properties of canned commodities. The Weibull model provided a 418 good description of the kinetics of degradation of antioxidant components in the range of 419 treatments therefore is appropriate for predictive purpose.

\section{Acknowledgements}

421 The authors would like to acknowledge the financial support of the DIT Strand I Research 422 Project (2006-2010). Thanks to Glanbia (Ltd Ingredients, Ireland) for supplying the whey 423 permeate, to Amcor Flexible Ltd. for providing OPP film and to Sharp Interpack for the 424 polypropylene trays. Special thanks to Dr. Nigel Brunton (Teagasc) for providing the pilot 425 scale facilities for canning the tomatoes.

\section{References}


Abushita, A. A., Daood, H. G., \& Biacs, P. A. (2000). Change in carotenoids and antioxidant vitamins in tomato as a function of varietal and technological factors. Journal of the Science of Food and Agriculture, 48, 2075-2081.

Ahmed, L., Martin-Diana, A. B., Rico, D., \& Barry-Ryan, C. (2011a). The antioxidant properties of whey permeate treated fresh-cut tomatoes. Food Chemistry, 124, 14511457.

Ahmed, L., Rico, D., Martin-Diana, A. B., \& Barry-Ryan, C. (2011b). Optimization of application of delactosed whey permeate treatment to extend the shelf-life of fresh-cut tomato using response surface methodology. Journal of Agricultural and Food Chemistry, 59, 2377-2385.

Ahmed, L., Martin-Diana, A. B., Rico, D., \& Barry-Ryan, C. (2011c). Quality and nutritional status of fresh-cut tomato as affected by spraying of delactosed whey permeate compared to industrial washing treatment. Food and Bioprocess Technology, DOI: 10.1007/s11947-011-0623-6.

Ahmed, L., Rico, D., Martin-Diana, A. B., \& Barry-Ryan, C. (2011d). Extending the shelflife of fresh-cut tomato using by-product from cheese industry. Journal of Food Processing and Preservation, DOI: 10.1111/j.1745-4549.2011.00562.x.

Arazuri, S., Jare’n, C., Arana, J. I., \& Pe'rez de Ciriza, J. J. (2007). Influence of mechanical harvest on the physical properties of processing tomato (Lycopersicon esculentum Mill.). Journal of Food Engineering, 80, 190-198.

Colbert, L. B., \& Decker, E. A. (1991). Antioxidant activity of an ultrafiltration permeate from acid whey. Journal of Food Science, 56, 1249-1250.

Contreras, M. del M., Hernández-Ledesma, B., Amigo, L., Martín-Álvarez, P. J., \& Recio, I. (2011). Production of antioxidant hydrolyzates from a whey protein concentrate with 
thermolysin: optimization by response surface methodology. LWT - Food Science and Technology, 44, 9-15.

453

454

455

456

457

458

459

460

461

462

463

464

465

466

467

468

469

470

471

472

473

Cunha, L. M., Oliveira, F. A. R., \& Oliveira, J. C. (1998). Optimal experimentaldesign for estimating the kinetic parameters of processes described by the Weibull probability distribution function. Journal of Food Engineering, 37, 175-191.

Dewanto, V., Wu, X., Adom, K. K., \& Liu, R. H. (2002). Thermal processing enhances the nutritional value of tomatoes by increasing total antioxidant activity. Journal of Agricultural and Food Chemistry, 50, 3010-3014.

Durance, T. D. (1997). Improving canned food quality with variable retort temperature processes. Trends in Food Science and Technology, 8, 113-118.

Ferreira, V. O., Pinho, O., Amaral, M. \& Martins, I. (2008). Application of blended-learning strategies on sensory analysis teaching. In M. Munoz, I. Jelinek, and F. Ferreira (Eds.). Proceedings of the IASK International Conference Teaching and Learning, pp. 262-270, Aveiro, Portugal.

Lana, M. M, Tijskens, L. M. M., \& Van Kooten, O. (2006). Effects of storage temperature and stage of ripening on rgb colour aspects of fresh-cut tomato pericarp using video image analysis. Journal of Food Engineering, 77, 871-879.

Lavelli, V., \& Giovanelli, G. (2003). Evaluation of heat and oxidative damage during storage of processed tomato products II. Study of oxidative damage indices. Journal of the Science of Food and Agriculture, 83, 966-971.

Lavelli, V., Hippeli, S., Peri, C., \& Elstner, E. F. (1999). Evaluation of radical scavenging activity of fresh and air-dried tomatoes by three model reactions. Journal of Agricultural and Food Chemistry, 47, 3826-3831. 
Lee H. S., \& Castle, W. S. (2001). Seasonal changes of carotenoid pigments and color in Hamlin, Eartygold, and Budd Blood orange juices. Journal of Agricultural \& Food Chemistry, 49, 877-882.

Liu, F., Cao, X., Wang, H., \& Liao, X. (2010). Changes of tomato powder qualities during storage. Powder Technology, 204, 159-166.

Manso, M. C., Oliveira, F. A. R., Oliveira, J. C., \& Frías, J. M. (2001). Modelling ascorbic 480 acid thermal degradation and browning in orange juice under aerobic conditions. International Journal of Food Science and Technology, 36, 303-312.

Marshall, K. (2004). Therapeutical applications of whey protein. Alternative Medicine 483 Review, 9, 136-156.

Martin-Diana, A. B., Rico, D., Frias, J. M., Mulcahy, J., Henehan, G. T. M., \& Barry- Ryan, 485 C. (2006). Whey permeate as a bio-preservative for shelf life maintenance of fresh486 cut vegetables. Innovative Food Science and Emerging Technology, 7, 112-123.

Martin-Diana, A. B., Rico, D., Frias, J. M., Barat, J. M., Henehan, G. T. M., \& Barry-Ryan, C. (2007). Calcium for extending the shelf life of fresh whole and minimally processed fruits and vegetables: a review. Trends in Food Science \& Technology, 18, 210-218.

490

Neter, J., Wasserman, W., \& Whitmore, G. A. (1992). Applied Statistics (4th ed.), (pp. 1989). Prentice Hall, Englewood cliffs, NJ.

Nykänen, A., Lapvetelainen, A., Hietnen, R. M., \& Kallio, H. (1998). The effect of acetic acid, nisin-whey permeates sodium chloride and related combinations on aerobic plate count and the sensory characteristics of rainbow trout. LWT - Food Science and Technology, 3, 286-290.

Odriozola-Serrano, I., Soliva-Fortuny, R., \& Martín-Belloso, O. (2009). Influence of storage 497 temperature on the kinetics of the changes in anthocyanins, vitamin $\mathrm{C}$ and antioxidant 
capacity in fresh-cut strawberries stored under high oxygen atmospheres. Journal of Food Science, 74, 184-191.

Ordóñez-Santos, L. E., Vázquez-Odériz, L., Arbones-Maciñeira, E., \& Romero-Rodríguez, M. A. (2009). The influence of storage time on micronutrients in bottled tomato pulp. Food Chemistry, 112, 146-149.

Patras, A., Brunton, N., Pieve, S. D, Butler, F., \& Downey, F. (2009). Effect of thermal and high pressure processing on antioxidant activity and instrumental colour of tomato and carrot purées. Innovative Food Science and Emerging Technologies, 10, 16-22.

Peña-Ramos, E. A., \& Xiong, Y. L. (2003). Whey and soy protein hydrolysates inhibit lipid oxidation in cooked pork patties. Meat Science, 64, 259-263.

Pinelo, M., Arnous, A. \& Meyer, A. S. (2006). Upgrading of grape skins: Significance of plant cell-wall structural components and extraction techniques for phenol release. Trends in Food Science and Technology, 17, 579-590.

Sanchez-Moreno, C. (2002). Methods used to evaluate the free radical scavenging activity in foods and biological systems. Food Science and Technology International, 8, 121-137.

Seybold, C., Fröhlich, K., Bitsch, R., Otto, K., \& Böhm, V. (2004). Changes in Contents of Carotenoids and Vitamin E during Tomato Processing Journal of Agricultural and Food Chemistry, 52, 7005-7010.

Sgherri, C., Kadlecova, Z., Pardossi, A., Navari-Izzo, F., \& Izzo, R. (2008). irrigation with

Shafiee, M., Taghavi, T. S., \& Babalar, M. (2010). Addition of salicylic acid to nutrient solution combined with postharvest treatments (hot water, salicylic acid, and calcium dipping) improved postharvest fruit quality of strawberry. Scientia Horticulturae, 124, 40-45. 
523 Shi, J., \& Le Maguer, M. (2000). Lycopene in tomatoes: chemical and physical properties affected by food processing. Critical Reviews in Food Science and Nutrition, 40, 1 - 42.

Singleton, V. L., Orthofer, R., \& Lamuela-Raventos, R. R. (1999). Analysis of total phenols and other oxidation substrates and oxidants by means of Folin-Ciocalteu reagent. Methods in Enzymology, 299, 152-178.

Stratil, P., Klejdus, B., \& Kuban, V. (2006). Determination of total content of phenolic compounds and their antioxidant activity in vegetables - evaluation of spectrophotometric methods. Journal of Agricultural Food Chemistry, 54, 607-616.

531 Tamburini, R., Sandei, L., Aldini, A., de, F., \& Leoni, C. (1999). Effect of storage conditions on lycopene content in tomato purees obtained with different processing techniques. Industria Conserve, 74, 341-357.

534 Taoukis, P., Labuza, T. P., Saguy, I. S. (1997). Kinetics of food deterioration and shelf life prediction. In: Valentas, K.J., Rostein, E., Singh, R.P. (Eds.), Handbook of food engineering practice (pp. 361-404). CRC Press, Boca Raton, FL.

Toor, R. K., \& Savage, G. P. (2005). Antioxidant activities in different fractions of tomato. 
541 Figure 1. Sensory evaluation of canned Irish plum tomatoes treated with $\mathrm{NaCl}+\mathrm{Citric}$ acid $(\square)$, DWP (口), DWP+ NaCl + citric acid $(\mathbf{\Delta})$ during the 6 months storage. Results are 543 expressed as independent determinations from three replicate analyses (mean of three 544 repetitions $)$. Colour $(9=$ bright red, $1=$ darkened $)$; Aroma $(9=$ strawberry like, $1=$

545 fermented); Texture $(9=$ very crispy, $1=$ soft $)$; General acceptability $(9=$ excellent, $1=$ 546 poor).

547 Figure 2. Changes in texture (A) and ascorbic acid (B) of canned Irish plum tomatoes treated 548 with $\mathrm{NaCl}+$ Citric acid $(\square)$, DWP $(\square), \mathrm{DWP}+\mathrm{NaCl}+$ citric acid $(\boldsymbol{\Delta})$ during the 6 months 549 storage as modeled by Weibull approach. Results are expressed as independent 550 determinations from three replicate analyses (mean of three repetitions). Plotted lines 551 correspond to the values estimated from the Weibull model from three replicate analyses.

552 Figure 3. Changes in antioxidant activity - DPPH (A) and FRAP (B) of canned Irish plum 553 tomatoes treated with $\mathrm{NaCl}+$ Citric acid DWP ( $\square), \quad \mathrm{DWP}+\mathrm{NaCl}+$ citric acid

554 during the 6 months storage as modeled by Weibull approach. Results are expressed as 555 independent determinations from three replicate analyses (mean of three repetitions). Plotted 556 lines correspond to the values estimated from the Weibull model from three replicate 557 analyses. 
Figure 1.

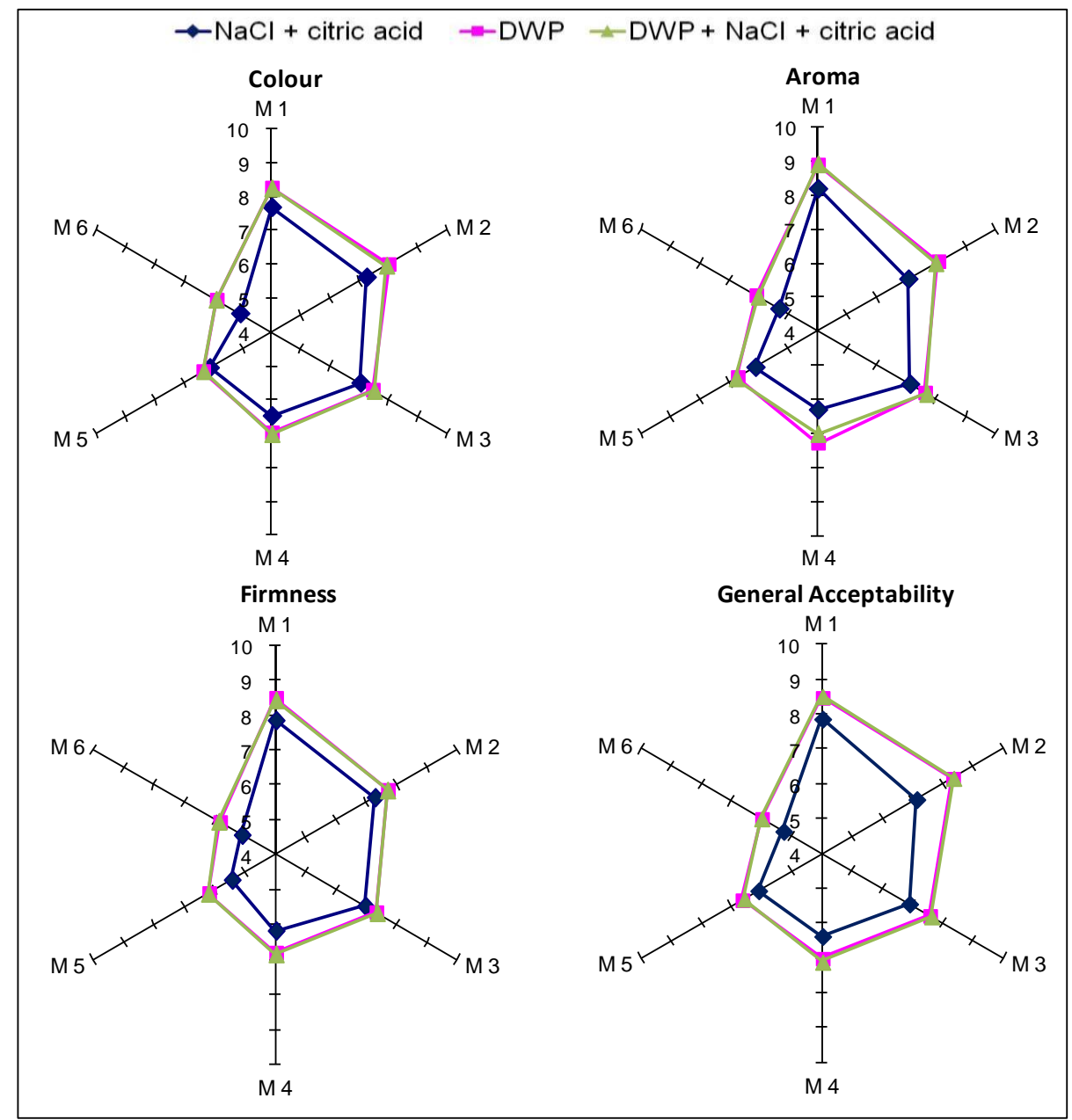


Figure 2
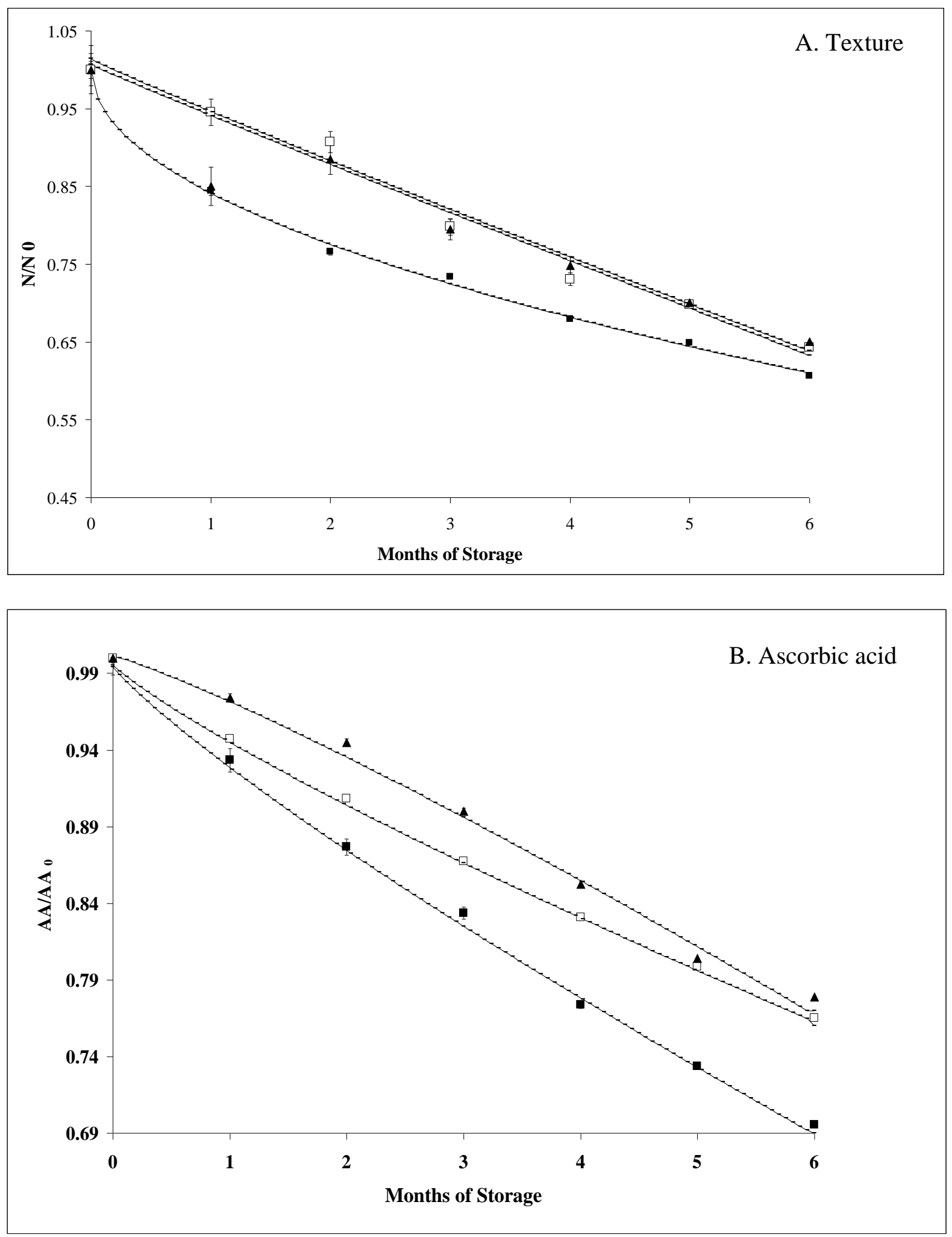
Figure 3
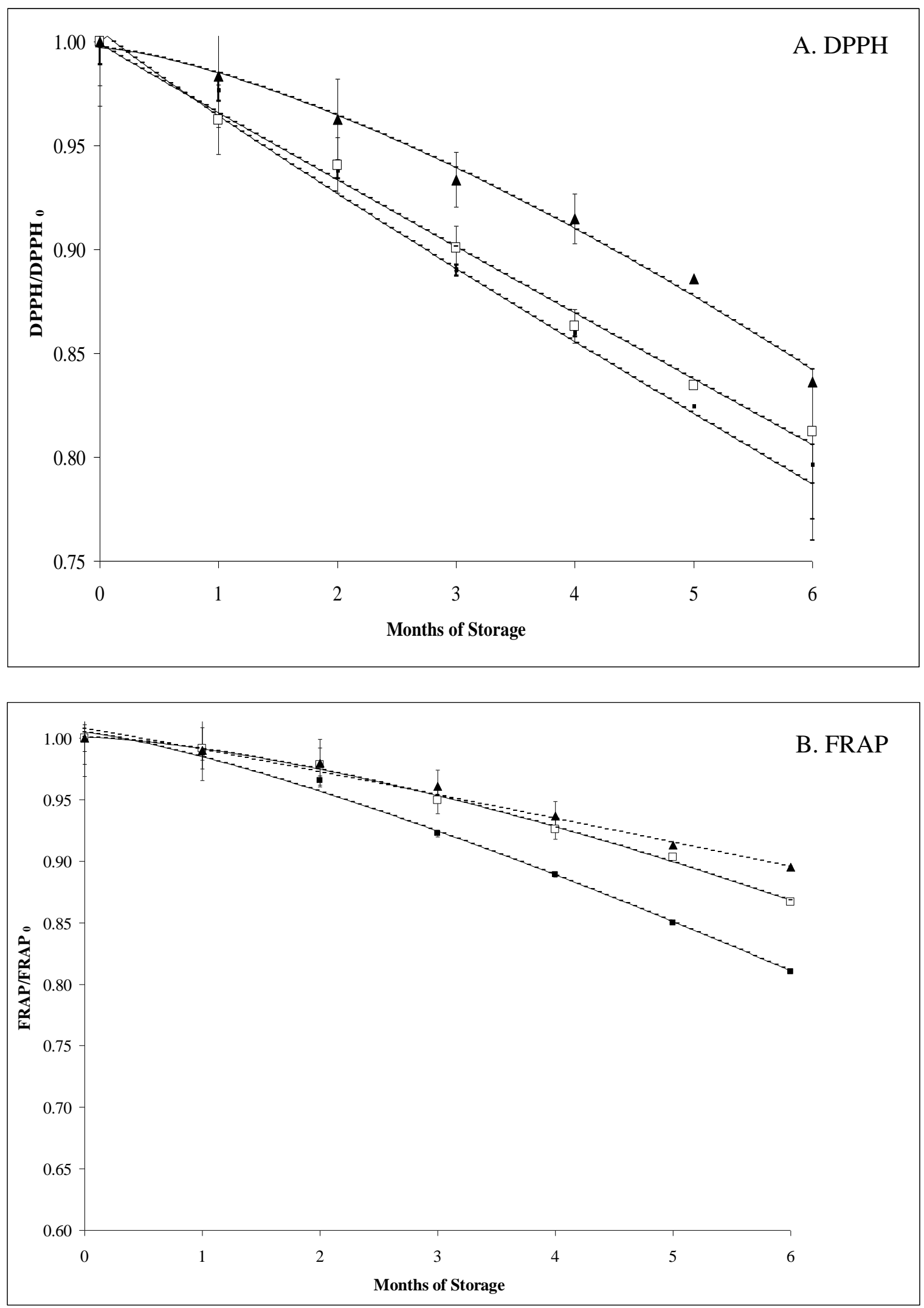
Table 1. Composition of Delactosed whey permeate (DWP).

\begin{tabular}{ll}
\hline DWP Components & Value \\
\hline $\mathrm{pH}$ & 5.0 \\
Total Solid \% & 32.90 \\
Lactose (\%) & 21.9 \\
Protein \% & 2.83 \\
Fat (\%) & minimal \\
Moisture \% & 91.4 \\
Ash \% & 8.14 \\
\hline
\end{tabular}


Table 2. Changes in phytochemical content of canned Irish plum tomatoes treated with DWP and/or NaCl+ Citric Acid during the 6 months of storage. ${ }^{1}$

${ }^{1}$ Values designated by the different letters are significantly different $(\mathrm{p}<0.05)$. Lowercase letters are used for comparisons during storage and

\begin{tabular}{|c|c|c|c|c|c|c|c|c|c|}
\hline \multirow[b]{2}{*}{ Markers } & \multirow[b]{2}{*}{ Treatments } & \multirow{2}{*}{$\begin{array}{l}\text { Significance } \\
\text { of } \\
\text { Difference }\end{array}$} & \multicolumn{7}{|c|}{ Storage (Months) } \\
\hline & & & 0 & 1 & 2 & 3 & 4 & 5 & 6 \\
\hline Ascorbic & $\mathrm{NaCl}+$ Citric Acid & $\mathrm{A}$ & $130.82^{\mathrm{g}}$ & $122.12^{f}$ & $114.70^{\text {de }}$ & $109.05^{\mathrm{d}}$ & $101.22^{\mathrm{c}}$ & $95.98^{\mathrm{b}}$ & $91.00^{\mathrm{a}}$ \\
\hline \multirow{2}{*}{ Acid } & DWP & B & $141.40^{\mathrm{h}}$ & $133.90^{\mathrm{g}}$ & $128.40^{\mathrm{fg}}$ & $122.60^{\mathrm{f}}$ & $117.50^{\mathrm{e}}$ & $112.90^{\mathrm{de}}$ & $108.20^{\mathrm{d}}$ \\
\hline & $\mathrm{DWP}+\mathrm{NaCl}+$ Citric Acid & $\mathrm{C}$ & $143.52^{\mathrm{h}}$ & $139.78^{\mathrm{gh}}$ & $135.62^{\mathrm{g}}$ & $129.15^{\mathrm{fg}}$ & $122.32^{\mathrm{f}}$ & $115.38^{\mathrm{de}}$ & $111.77^{\mathrm{de}}$ \\
\hline \multirow[t]{3}{*}{ Lycopene } & $\mathrm{NaCl}+$ Citric Acid & A & $108.30^{\mathrm{b}}$ & $107.80^{\mathrm{b}}$ & $105.50^{\mathrm{ab}}$ & $106.60^{\mathrm{b}}$ & $104.70^{\mathrm{ab}}$ & $102.80^{\mathrm{a}}$ & $104.10^{\mathrm{ab}}$ \\
\hline & DWP & B & $120.20^{\mathrm{d}}$ & $116.50^{\mathrm{cd}}$ & $115.80^{\mathrm{cd}}$ & $113.30^{\mathrm{c}}$ & $115.80^{\mathrm{cd}}$ & $115.50^{\mathrm{cd}}$ & $114.00^{\mathrm{c}}$ \\
\hline & $\mathrm{DWP}+\mathrm{NaCl}+$ Citric Acid & $\mathrm{C}$ & $125.30^{\mathrm{e}}$ & $123.30^{\mathrm{e}}$ & $122.00^{\mathrm{de}}$ & $122.70^{\mathrm{de}}$ & $121.80^{\mathrm{de}}$ & $121.20^{\mathrm{de}}$ & $121.00^{\mathrm{de}}$ \\
\hline Total & $\mathrm{NaCl}+$ Citric Acid & A & $290.60^{\mathrm{a}}$ & $292.00^{\mathrm{ab}}$ & $294.70^{\mathrm{b}}$ & $295.20^{\mathrm{b}}$ & $297.80^{c}$ & $298.80^{\mathrm{cd}}$ & $300.70^{\mathrm{d}}$ \\
\hline \multirow{2}{*}{ Phenol } & DWP & B & $304.40^{\mathrm{e}}$ & $305.30^{\mathrm{e}}$ & $306.20^{\mathrm{e}}$ & $308.20^{\mathrm{f}}$ & $310.30^{\mathrm{g}}$ & $311.60^{\mathrm{gh}}$ & $312.40^{\mathrm{gh}}$ \\
\hline & $\mathrm{DWP}+\mathrm{NaCl}+$ Citric Acid & $\mathrm{C}$ & $305.30^{\mathrm{e}}$ & $306.20^{\mathrm{e}}$ & $307.40^{\mathrm{ef}}$ & $309.30^{\mathrm{f}}$ & $311.40^{\mathrm{gh}}$ & $312.10^{\mathrm{gh}}$ & $314.10^{\mathrm{h}}$ \\
\hline \multirow[t]{3}{*}{ DPPH } & $\mathrm{NaCl}+$ Citric Acid & A & $64.67^{\mathrm{e}}$ & $63.17^{\mathrm{de}}$ & $60.67^{\mathrm{d}}$ & $56.67^{\mathrm{c}}$ & $54.50^{\mathrm{b}}$ & $53.33^{\mathrm{b}}$ & $51.50^{\mathrm{a}}$ \\
\hline & DWP & $\mathrm{B}$ & $75.50^{\mathrm{fg}}$ & $72.67^{\mathrm{f}}$ & $71.00^{\mathrm{f}}$ & $68.00^{\text {ef }}$ & $65.17^{\mathrm{e}}$ & $63.00^{\mathrm{de}}$ & $61.33^{\mathrm{d}}$ \\
\hline & $\mathrm{DWP}+\mathrm{NaCl}+$ Citric Acid & $\mathrm{C}$ & $80.33^{\mathrm{g}}$ & $79.00^{\mathrm{g}}$ & $77.33^{\mathrm{fg}}$ & $75.00^{\mathrm{fg}}$ & $73.50^{\mathrm{f}}$ & $71.17^{\mathrm{f}}$ & $67.17^{\mathrm{ef}}$ \\
\hline \multirow[t]{3}{*}{ FRAP } & $\mathrm{NaCl}+$ Citric Acid & A & $1197.30^{\mathrm{fg}}$ & $1182.50^{\mathrm{f}}$ & $1156.10^{\mathrm{e}}$ & $1104.50^{\mathrm{cd}}$ & $1064.70^{\mathrm{b}}$ & $1000.80^{\mathrm{ab}}$ & $983.80^{\mathrm{a}}$ \\
\hline & DWP & B & $1213.80^{\mathrm{g}}$ & $1203.80^{\mathrm{fg}}$ & $1187.80^{f}$ & $1152.50^{\mathrm{e}}$ & $1124.00^{\mathrm{d}}$ & $1096.70^{\mathrm{c}}$ & $1052.30^{\mathrm{b}}$ \\
\hline & $\mathrm{DWP}+\mathrm{NaCl}+$ Citric Acid & $\mathrm{C}$ & $1216.50^{\mathrm{g}}$ & $1204.60^{\mathrm{fg}}$ & $1191.70^{\mathrm{f}}$ & $1168.80^{\mathrm{e}}$ & $1139.50^{\mathrm{d}}$ & $1110.70^{\mathrm{cd}}$ & $1089.20^{\mathrm{C}}$ \\
\hline
\end{tabular}

uppercase letters for treatment comparisons. The method used to discriminate among the means is Fisher's least significant difference (LSD) procedure. 
Table 3. Changes in texture and colour of canned Irish plum tomatoes treated with DWP and/or NaCl + citric acid during the 6 months of storage. ${ }^{1}$

\begin{tabular}{|c|c|c|c|c|c|c|c|c|c|}
\hline \multirow{2}{*}{ Markers } & \multirow{2}{*}{ Treatments } & \multirow{2}{*}{$\begin{array}{l}\text { Significance } \\
\text { of Difference }\end{array}$} & \multicolumn{7}{|c|}{ Storage (Months) } \\
\hline & & & 0 & 1 & 2 & 3 & 4 & 5 & 6 \\
\hline \multirow[t]{3}{*}{ Texture } & $\mathrm{NaCl}+$ Citric Acid & $\mathrm{A}$ & $4.17^{\mathrm{fg}}$ & $3.52^{\mathrm{de}}$ & $3.19^{\mathrm{cd}}$ & $3.06^{\mathrm{c}}$ & $2.83^{\mathrm{b}}$ & $2.71^{\mathrm{ab}}$ & $2.53^{\mathrm{a}}$ \\
\hline & DWP & $\mathrm{B}$ & $5.09^{\mathrm{gh}}$ & $4.81^{\mathrm{g}}$ & $4.62^{\mathrm{g}}$ & $4.06^{\mathrm{f}}$ & $3.72^{\mathrm{e}}$ & $3.56^{\mathrm{de}}$ & $3.27^{\mathrm{d}}$ \\
\hline & $\mathrm{DWP}+\mathrm{NaCl}+\mathrm{Citric}$ Acid & $\mathrm{C}$ & $5.45^{\mathrm{h}}$ & $5.35^{\mathrm{h}}$ & $4.82^{\mathrm{g}}$ & $4.33^{\mathrm{fg}}$ & $4.08^{\mathrm{f}}$ & $3.82^{\mathrm{e}}$ & $3.55^{\mathrm{de}}$ \\
\hline \multicolumn{10}{|c|}{ 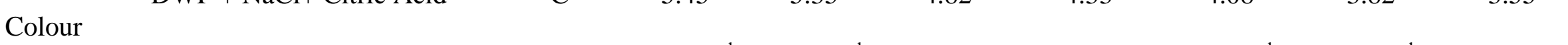 } \\
\hline \multirow[t]{3}{*}{$\mathrm{L}^{*}$} & $\mathrm{NaCl}+$ Citric Acid & A & $22.20^{\mathrm{de}}$ & $21.95^{\mathrm{d}}$ & $21.36^{\mathrm{c}}$ & $21.16^{\mathrm{c}}$ & $20.78^{\mathrm{bc}}$ & $20.37^{\mathrm{b}}$ & $19.58^{\mathrm{a}}$ \\
\hline & DWP & $\mathrm{B}$ & $24.82^{\mathrm{fg}}$ & $24.84^{\mathrm{fg}}$ & $24.14^{\mathrm{f}}$ & $23.32^{\mathrm{e}}$ & $22.72^{\mathrm{de}}$ & $22.22^{\mathrm{de}}$ & $21.76^{\mathrm{d}}$ \\
\hline & $\mathrm{DWP}+\mathrm{NaCl}+$ Citric Acid & $\mathrm{C}$ & $25.50^{\mathrm{g}}$ & $24.47^{\mathrm{f}}$ & $24.19^{\mathrm{f}}$ & $23.44^{\mathrm{e}}$ & $23.08^{\mathrm{e}}$ & $22.62^{\mathrm{de}}$ & $22.12^{\mathrm{d}}$ \\
\hline \multirow[t]{3}{*}{$a^{*}$} & $\mathrm{NaCl}+$ Citric Acid & A & $9.49^{c}$ & $9.26^{\mathrm{bc}}$ & $9.07^{\mathrm{bc}}$ & $8.80^{\mathrm{b}}$ & $8.64^{\mathrm{b}}$ & $8.41^{\mathrm{b}}$ & $8.01^{\mathrm{a}}$ \\
\hline & DWP & $\mathrm{B}$ & $12.80^{\mathrm{f}}$ & $12.47^{\text {ef }}$ & $12.31^{\mathrm{e}}$ & $12.10^{\mathrm{de}}$ & $12.06^{\mathrm{de}}$ & $11.84^{\mathrm{d}}$ & $11.75^{\mathrm{d}}$ \\
\hline & $\mathrm{DWP}+\mathrm{NaCl}+\mathrm{Citric}$ Acid & $\mathrm{C}$ & $13.08^{\mathrm{f}}$ & $12.91^{\mathrm{f}}$ & $12.73^{\mathrm{f}}$ & $12.62^{\text {ef }}$ & $12.55^{\text {ef }}$ & $12.41^{\mathrm{e}}$ & $12.22^{\mathrm{e}}$ \\
\hline \multirow[t]{3}{*}{$b^{*}$} & $\mathrm{NaCl}+$ Citric Acid & A & $23.58^{\mathrm{d}}$ & $23.29^{\mathrm{c}}$ & $23.18^{\mathrm{c}}$ & $22.82^{b c}$ & $22.62^{\mathrm{b}}$ & $22.45^{\mathrm{b}}$ & $22.23^{\mathrm{a}}$ \\
\hline & DWP & $\mathrm{B}$ & $25.09^{\mathrm{fg}}$ & $24.62^{\mathrm{f}}$ & $24.33^{\text {ef }}$ & $24.10^{\mathrm{e}}$ & $23.79^{\mathrm{de}}$ & $23.60^{\mathrm{d}}$ & $23.29^{\mathrm{c}}$ \\
\hline & $\mathrm{DWP}+\mathrm{NaCl}+\mathrm{Citric}$ Acid & $\mathrm{C}$ & $25.87^{\mathrm{h}}$ & $25.55^{\mathrm{g}}$ & $25.31^{\mathrm{fg}}$ & $25.07^{\mathrm{tg}}$ & $24.80^{\mathrm{f}}$ & $24.72^{\mathrm{f}}$ & $24.46^{\mathrm{ef}}$ \\
\hline \multirow[t]{3}{*}{ Hue } & $\mathrm{NaCl}+$ Citric Acid & A & $68.07^{\mathrm{c}}$ & $68.32^{\mathrm{c}}$ & $68.62^{\mathrm{cd}}$ & $68.92^{\mathrm{d}}$ & $69.10^{\mathrm{e}}$ & $69.47^{\mathrm{ef}}$ & $70.19^{\mathrm{f}}$ \\
\hline & DWP & $\mathrm{B}$ & $62.97^{\mathrm{a}}$ & $63.13^{\mathrm{ab}}$ & $63.16^{\mathrm{ab}}$ & $63.34^{\mathrm{b}}$ & $63.11^{\mathrm{ab}}$ & $63.36^{\mathrm{b}}$ & $63.24^{\mathrm{ab}}$ \\
\hline & $\mathrm{DWP}+\mathrm{NaCl}+\mathrm{Citric}$ Acid & $\mathrm{C}$ & $63.18^{\mathrm{ab}}$ & $63.19^{\mathrm{ab}}$ & $63.30^{\mathrm{ab}}$ & $63.28^{\mathrm{b}}$ & $63.16^{\mathrm{ab}}$ & $63.34^{\mathrm{b}}$ & $63.45^{\mathrm{b}}$ \\
\hline \multirow[t]{3}{*}{ Chroma } & $\mathrm{NaCl}+$ Citric Acid & A & $25.42^{\text {cd }}$ & $25.07^{\mathrm{c}}$ & $24.89^{c}$ & $24.46^{\mathrm{bc}}$ & $24.21^{\mathrm{bc}}$ & $23.98^{b}$ & $23.63^{\mathrm{a}}$ \\
\hline & DWP & $\mathrm{B}$ & $28.17^{\mathrm{fg}}$ & $27.59^{f}$ & $27.26^{\mathrm{ef}}$ & $26.96^{\mathrm{e}}$ & $26.67^{\mathrm{de}}$ & $26.41^{\mathrm{de}}$ & $26.08^{\mathrm{d}}$ \\
\hline & $\mathrm{DWP}+\mathrm{NaCl}+\mathrm{Citric}$ Acid & $\mathrm{C}$ & $28.99^{\mathrm{g}}$ & $28.62^{\mathrm{g}}$ & $28.33^{\mathrm{fg}}$ & $28.07^{\mathrm{fg}}$ & $27.79^{\mathrm{f}}$ & $27.66^{\mathrm{f}}$ & $27.34^{\mathrm{ef}}$ \\
\hline
\end{tabular}

${ }^{\mathrm{T}}$ Values designated by the different letters are significantly different $(\mathrm{p}<0.05)$. Lowercase letters are used for comparisons during storage and uppercase letters for treatment comparisons. The method used to discriminate among the means is Fisher's least significant difference (LSD) procedure. 
Table 4. Kinetic constants of Weibull distribution function (Eq. (1)) for texture, ascorbic acid, and total antioxidant activity.

\begin{tabular}{|c|c|c|c|c|c|c|}
\hline Markers & Treatments & $\mathrm{k}^{\mathrm{a}}$ ( $1 /$ month $)$ & $\beta^{\mathrm{b}}$ & $\mathrm{R}^{2}$ & $\mathrm{R}_{\mathrm{adj}}^{2}$ & $\mathrm{RMSE}^{\mathrm{C}}$ \\
\hline \multirow[t]{3}{*}{ Texture } & $\mathrm{NaCl}+$ citric acid & 0.025 & 0.50 & 0.99 & 0.99 & 0.0075 \\
\hline & DWP & 0.060 & 0.98 & 0.98 & 0.97 & 0.0218 \\
\hline & $\mathrm{DWP}+\mathrm{NaCl}+$ Citric acid & 0.050 & 0.96 & 0.97 & 0.96 & 0.0242 \\
\hline \multirow[t]{3}{*}{ Ascorbic acid } & $\mathrm{NaCl}+$ citric acid & 0.041 & 0.84 & 0.99 & 0.99 & 0.0051 \\
\hline & DWP & 0.029 & 0.84 & 0.99 & 0.99 & 0.0014 \\
\hline & $\mathrm{DWP}+\mathrm{NaCl}+$ Citric acid & 0.047 & 1.16 & 0.99 & 0.99 & 0.0083 \\
\hline \multirow[t]{3}{*}{$\mathrm{DPPH}^{\mathrm{d}}$} & $\mathrm{NaCl}+$ citric acid & 0.032 & 0.93 & 0.97 & 0.96 & 0.9632 \\
\hline & DWP & 0.031 & 0.98 & 0.99 & 0.99 & 0.0062 \\
\hline & $\mathrm{DWP}+\mathrm{NaCl}+$ Citric acid & 0.045 & 1.43 & 0.99 & 0.98 & 1.1938 \\
\hline \multirow[t]{3}{*}{ FRAP $^{\mathrm{e}}$} & $\mathrm{NaCl}+$ citric acid & 0.045 & 1.27 & 0.98 & 0.97 & 0.0107 \\
\hline & DWP & 0.042 & 1.48 & 0.99 & 0.99 & 0.0036 \\
\hline & $\mathrm{DWP}+\mathrm{NaCl}+$ Citric acid & 0.021 & 1.50 & 0.98 & 0.97 & 0.0064 \\
\hline
\end{tabular}

${ }^{a}$ rate constant; ${ }^{b}$ shape factor; ${ }^{\mathrm{c}}$ Root Mean Sum of Squared Error

d 2, 2-Diphenyl-1-picrylhydrazyl radical scavenging activity (\% reduction)

${ }^{\mathrm{e}}$ Ferric ion reducing antioxidant power (mg Trolox /100 g DW) 